Section Editor

Mitchell S.V. Elkind, MD, MS

Shevantha Rosa, FRCR Indran Davagnanam, FRCR

Correspondence \& reprint requests to Dr. Davagnanam: indrandavagnanam@gmail.com

\title{
Teaching NeuroImages: Bilateral pedicular fractures in severe lumbar dural ectasia
}

\section{Figure $1 \quad$ Sagittal CT}

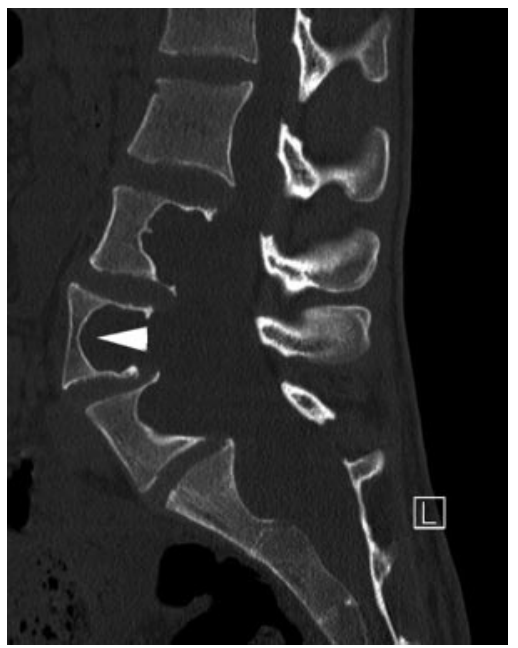

Imaging shows evidence of dural ectasia with posterior vertebral body scalloping (arrowhead). A mild L4/5 anterolisthesis is present.

A 20-year-old man with neurofibromatosis I presented with back pain and altered sensation in the lower limbs without a radicular distribution and normal power. He subsequently developed urinary retention and reduced sensation to the level of T10. MRI and CT examinations performed to exclude cord compression demonstrated dural ectasia (expansion of the dural sac) resulting in elongated lumbar pedicles and bilateral chronic fractures (figures 1 and 2). Pedicular fractures are a recognized but rare

\section{Figure $2 \quad$ Axial CT}

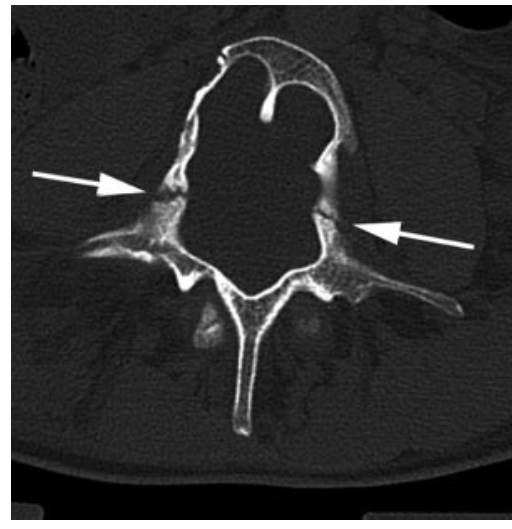

The lumbar pedicles were elongated and thinned with bilateral pedicular fractures (arrows). The fractures showed no edema on MRI suggesting chronic nonunited fractures.

complication of dural ectasia. ${ }^{1}$ It is postulated that pedicular weakness secondary to thinning relate to dural ectasia and result in stress fractures. ${ }^{2}$

\section{AUTHOR CONTRIBUTIONS}

Dr. Rosa: collation of images, literature search, manuscript, and submission. Dr. Davagnanam: content ideas, reviewing and editing, corresponding author.

\section{REFERENCES}

1. Mandell GA. The pedicle in neurofibromatosis. AJR Am J Roentgenol 1978;130:675.

2. Bensaid AH, Dietemann JL, Kastler B, Gangi A, Jeung MY, Wackenheim A. Neurofibromatosis with dural ectasia and bilateral symmetrical pedicular clefts: report of two cases. Neuroradiol 1992;34:107-109. 


\section{Neurology}

\section{Teaching NeuroImages: Bilateral pedicular fractures in severe lumbar dural ectasia Shevantha Rosa and Indran Davagnanam}

Neurology 2012;78; 11

DOI 10.1212/WNL.0b013e31823efcd4

\section{This information is current as of January 9, 2012}

Updated Information \& Services

References

Subspecialty Collections

Permissions \& Licensing

Reprints including high resolution figures, can be found at: http://n.neurology.org/content/78/2/e11.full

This article cites 2 articles, 0 of which you can access for free at: http://n.neurology.org/content/78/2/e11.full\#ref-list-1

This article, along with others on similar topics, appears in the following collection(s):

CT

http://n.neurology.org/cgi/collection/ct

Other Education

http://n.neurology.org/cgi/collection/other_education

Information about reproducing this article in parts (figures,tables) or in its entirety can be found online at:

http://www.neurology.org/about/about_the_journal\#permissions

Information about ordering reprints can be found online:

http://n.neurology.org/subscribers/advertise

Neurology ${ }^{\circledR}$ is the official journal of the American Academy of Neurology. Published continuously since 1951, it is now a weekly with 48 issues per year. Copyright Copyright (? 2012 by AAN Enterprises, Inc.. All rights reserved. Print ISSN: 0028-3878. Online ISSN: 1526-632X.

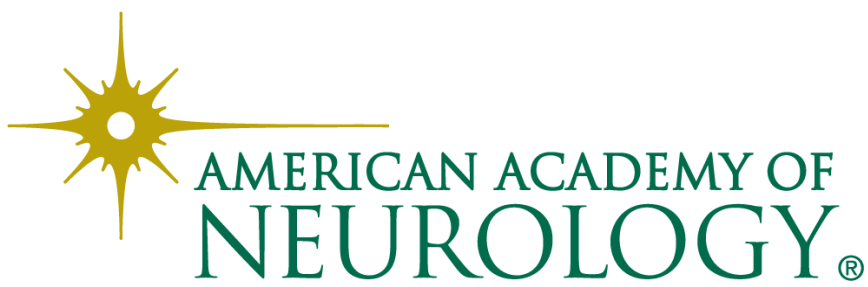

